\title{
Silver City: A Case Study
}

John R. Mills, University of Nevada Reno, USA

Sonja Pippin, University of Nevada Reno, USA

Charles Carslaw, University of Nevada Reno, USA

Richard Mason, University of Nevada Reno, USA

\begin{abstract}
The Silver City Case is designed for an advanced accounting or MBA class and provides students with the opportunity to analyze relevant information extracted from different types of business entities. These range from publicly traded corporations to non-corporate and/or non-public entities. Students are required to make a decision on the viability of a bid on a Request for Proposal (RFP) for a sports facility construction project. The primary objective is to provide a foundation for the evaluation of complex business entities. This requires the dismantling of the business structure to the point that it can be analyzed on an individual entity basis. The achievement of this objective requires students to understand the type of financial information that can be derived from each of the different entities as well as determining the reliability of such information. Furthermore, the case offers opportunities to discuss underlying guarantees that keep the business structures together.
\end{abstract}

Keywords: business entities, financial ratios, financial analysis, flow-through entities, RFPs, guarantees

\section{INTRODUCTION}<smiles>[C]1C=CCCC1</smiles>

ilver City is a city in the western United States that at one time was a boom town during the gold rush period. It had a population in excess of 100,000 in the 1860s and its current population has grown to over 300,000. Parts of the old central downtown area of the city have become depopulated and are in run down condition. The city has started a series of redevelopment projects in its effort to attract more people to live and work in the downtown community. One of the projects is the construction of a Silver Spurs Sports Facility. The city has put out a Request for Proposal (RFP) for the construction, operation and ownership of this sports facility. The city currently owns the land that the Silver Spurs Sports Facility will be built on but will donate the land to the winner of the proposal. The RFP was announced in April 2009. The evaluation process will commence on June 30, 2009 and the winning bid will be announced on September 1, 2009. Construction is expected to start October 1, 2009.

The RFP has resulted in the submission of several proposals by companies with a range of ownership structures. The submissions include bidders from publicly traded corporations who have created Limited Liability Company ("LLC") subsidiaries; joint ventures and other ownership structures. Other submissions come from newly created LLCs composed of a combination of individual investors, partnerships, trusts and LLCs. All the proposers submitted financial information with a year end of December 31, 2008.

The City Council of Silver City selected a group of five senior government officials to be the Sports Facility Review Board (SFRB) ("Board"). The Board will decide on the winning proposal. In addition, the Council decided to hire a group of experts to provide advice to the Board based on their expertise in the areas of financial analysis, economic development, human resources, strategic and operational business plans, and sports complex design. You have been hired to provide the advice in the area of financial analysis.

An area of major concern to the Board is their lack of understanding of corporate financial information. Given the current weak economy, the Board wants assurance that the winner of the proposal has the financial capability to construct the project and the ability to operate the property for an extended period once it has been opened. The city has hired you to evaluate the financial suitability and stability of each of the applicants that have submitted RFPs. 


\section{EVALUATION OF AN ENTITY FOR FINANCIAL SUITABILITY}

The first applicant that has been referred to you for review is Top Hill Investments, LLC. The Board has provided you with the financial data provided in Appendix A that represents the financial information provided by the Top Hill Investment group. This information and the information below has been provided by Top Hill Investments' company president, John Burch.

Top Hill Investments is a newly formed entity created solely for the Silver Spurs Sports Facility RFP. The joint venture intends to build, own and manage the facility if awarded the bid. The owners are ABC2 Corporation and Silver Nugget, LLC. As shown in Figure 1, ABC2 and Silver Nugget are each 50\% owners of Top Hill Investments.

$\mathrm{ABC} 2$ is a wholly-owned subsidiary of $\mathrm{ABC}$ Corporation, a publicly-traded corporation (Nasdaq: $\mathrm{ABC}$ ) and the owner/operator of the Stockton City Sports Arena in California. ABC2 has been created by ABC solely as a subsidiary to establish Top Hill. It does not have any significant assets or liabilities. ABC has provided its historic financial statements for the three years ending December 31, 2008 (see Tables C1, C2, and C3).

Silver Nugget, LLC is also a newly-formed entity, formed solely in connection with Top Hill's application for the Silver Spurs Sports Facility proposal. Silver Nugget is a jointly owned company owned by three of the principal partners of BCD Construction Company (John Burch (70\%), Steven Cornwall (20\%) and Charles Jacobs $(10 \%))$. BCD Construction Company is a nationally-known private development company with extensive experience in the development of leading sports complexes.

Because Silver Nugget is a newly formed entity with no historical financial information, net worth statements (Table C4) and summarized tax return information (Table C5) of all of the investors in Silver Nugget have been included in the RFP. In addition to the net worth of its owners, Silver Nugget has arranged a further $\$ 150$ million undrawn line of credit (hard copy of credit agreement included) from the Burch Family II Trust. Information concerning the Burch Family II Trust is provided in Table C6. This trust was specifically set up by Burch family members to fund certain investments projects. Thus, while trust income is generally not distributed, the trustee has the flexibility to distribute trust assets to Burch family members and to pledge funds for certain investment projects.

\section{PROPOSED COST OF THE SILVER SPUR SPORTS FACILITY}

Top Hill has provided estimated cost information on the proposed Silver Spurs Sports Facility as shown in Table C7. The total proposed cost is estimated to be $\$ 700$ million. The cost includes $\$ 180$ million for highway improvements that will provide easier access to the stadium and parking. This was one of the required improvements suggested by the City in order to have a viable bid. Top Hill also submitted together with the bid a letter of intent from First West Bank which indicates the bank would be willing to extend a five year $\$ 400$ million senior security loan if the owners of Top Hill Investments make an upfront $\$ 300$ million equity contribution to the project. This type of arrangement between lending institution and bidder is relatively common. Top Hill must provide $\$ 300$ million in cash at the signing date of the agreement with the bank. Note that in order to be considered by the Board, they would expect the bank agreement to be in place at the time when the proposal is submitted.

Sports Facility Review Board wants advice about the financial viability of this proposal. The Board is apprehensive because the proposal from Top Hill Investments is from a newly formed corporation with no financial history. They are very impressed with the design of the proposed facility and the personalities of the proposers and they feel that the $\$ 700$ million cost is a reasonable estimate. They are, however, concerned about where the funds will come from for constructing and operating the sports facility. They are particularly worried about the reliability of the financial information provided by the Silver Nugget investors. They have asked you to provide them with a financial analysis that will enable them to decide whether this bid is a viable candidate for awarding the sports facility contract and to advise them on further information they should seek before finalizing their decision.

The SFRB also notes that the financials provided were for the year ending December 31, 2008. The current year (2009) has been identified as a recession year with anticipated recovery in the third quarter of 2010. They point 
out that the stock market has dropped considerably and that the bankers are being more restrictive about loans. After carefully evaluating all financial information provided to you, what is your advice to Board?

\section{POTENTIAL CASE QUESTIONS}

\section{A. Ownership Structure}

Develop an overview of the different types of business entities involved in this bid. Provide a summary of the strengths and weaknesses associated with each type of business enterprise. Specifically, research the following characteristics for each of the entity involved:

- $\quad$ Limited liability of the entity's owner(s)

- Tax treatment of the entity's earnings

- Tax treatment of contributions to and distributions from the entity

- $\quad$ Restrictions regarding who can be an owner of the entity

Remember that your presentation is to the Board who has very limited private business expertise.

\section{B. Publicly Traded Corporations}

1) Prepare a financial statement analysis for the Board on $\mathrm{ABC} 2$ 's parent $\mathrm{ABC}$. This should include both ratio and trend analysis.

a) Determine the financial ratios that are relevant to determine :

i. the liquidity of the companies,

ii. the solvency of the companies, and

iii. the profitability of the companies.

b) Identify the business group that should be used to make industry comparisons and identify appropriate benchmark ratios.

c) Provide an excel spreadsheet with the ratios and trends

2) Use this information to write a report providing recommendations in terms of the $\mathrm{ABC} 2$ 's and $\mathrm{ABC}$ 's ability to fund this project.

3) What additional information should you seek to evaluate this type of entity?

4) Would your answer be different if you were told that the ABC also has a $\$ 300$ million revolving bank line of credit?

\section{Non-Corporate and/or Non-Public Entities}

1) Identify problems that need to be addressed when dealing with the financial analysis of Silver Nugget and the net worth statements provided by its owners?

2) Cash flow statements are required to be provided with public corporations. Is it possible to prepare equivalent cash flow information from the information provided by the Silver Nugget owners?

3) If the Burch Family Trust contributes funding in the form of a loan, how should that funding be treated?

\section{All Entities Combined}

1) Develop a table that addresses the question of what each investor needs to contribute to the project and whether they can meet their expected input with the resources currently available.

2) Recall that the timeline of the project calls for submission of the proposals by June 30, 2009 when the evaluation process will commence. The winner will be announced by September 1 and construction is expected to start October 1 of the same year. As suggested in the text, the investors have to put guarantees in place to satisfy the Board as well as the bank. These guarantees will cover the time period from the submittal of the bid until construction starts. What nature and type of guarantee should be provided to cover this period of time? Are there any specific disclosure requirements for these guarantees? 


\section{AUTHOR INFORMATION}

John Mills is a Professor of Accounting at the University of Nevada, Reno. He holds a Doctor of Philosophy in Business Administration from the University of Colorado, Boulder, an MBA and a BS degree in Business Administration from the University of Nevada, Reno. His area of specialty is in financial accounting and disclosure. $\mathrm{He}$ has also specialized in consulting work dealing with casino accounting issues. He has published extensively on specialized topics such as cash flow analysis, money laundering regulations and casino controls and compliance testing.

Sonja Pippin is an Assistant Professor at the University of Nevada, Reno. She holds a Doctor of Philosophy in Business Administration and a Master's Degree in Accounting (Tax); both from Texas Tech University. She teaches tax courses with a focus on taxation of business entities and consults for a local CPA firm. She has published in several academic and practitioner-oriented journals. Her research interests include legal tax research, technology acceptance in the accounting and tax environment, and tax policy.

Richard Mason is Chair of Accounting and an Associate Professor at the University of Nevada, Reno. He holds a Doctor of Philosophy in Business Administration from the University of Connecticut, a Juris Doctor degree from St. John's University School of Law, and a BBA in Accounting from Hofstra University. He has been admitted to practice law in New York since 1981. His area of specialty is in taxation. He has published extensively on various tax and financial accounting topics.

Charles Carslaw is an Associate Professor at the University of Nevada Reno. He teaches intermediate, advanced and international accounting courses. He specializes in financial reporting issues and works extensively with Native American tribal governments and their commercial enterprises. He has published extensively in academic and practitioner journals. His research interests include specialized financial accounting \& auditing topics as well as government/not-for profit issues. 


\section{APPENDIX A}

\section{Ownership Structure and Financial Information of Top Hill Investments, LLC}

The investment proposal (RFP) for the Silver Spurs construction project is put forth by an investment entity with an ownership structure as presented in Figure 1 below. The investing company is owned by the Silver Nugget LLC, a new flow-through entity formed by three individuals: Burch, Cornwall, and Darwin. The other owner is a corporation owned by $\mathrm{ABC}$ Corporation, a public entity (C Corporation).

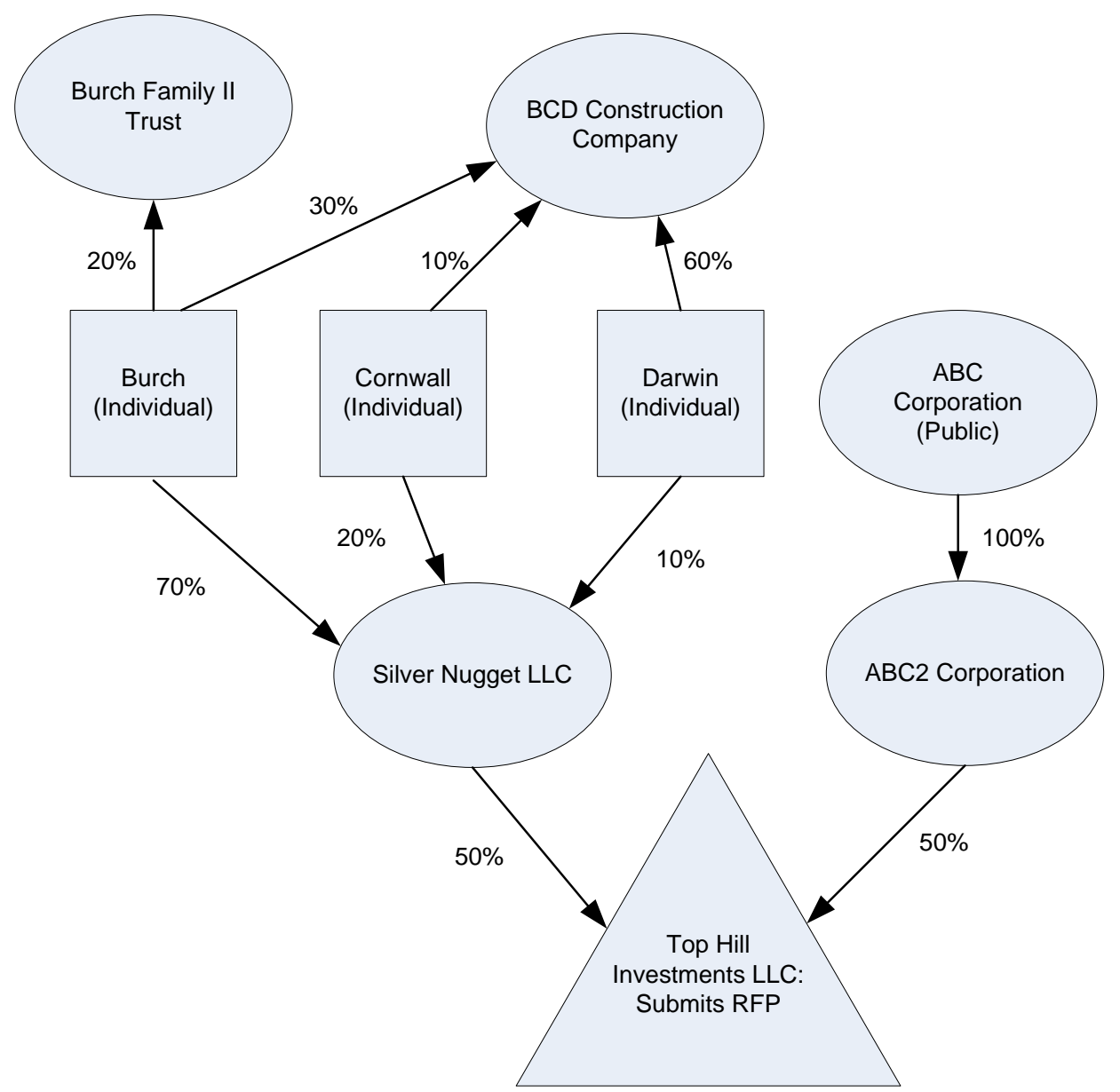

Figure 1: Ownership Structure 
Table C1: Balance Sheet

ABC Corporation

Statement of Financial Position

\begin{tabular}{|c|c|c|c|}
\hline \multicolumn{4}{|l|}{ In millions of USD } \\
\hline Assets & $12 / 31 / 2008$ & 12/31/2007 & $12 / 31 / 2006$ \\
\hline Cash & $\$ \quad 57.32$ & 59.68 & $\$ 130.76$ \\
\hline Marketable Securities & 39.25 & 78.00 & 8.20 \\
\hline Receivables & 46.86 & 52.70 & 45.56 \\
\hline Inventories & 4.51 & 3.98 & 6.53 \\
\hline Other Current Assets & 11.89 & 9.25 & 6.34 \\
\hline Total Current Assets & 159.83 & 203.61 & 197.39 \\
\hline Prop., Plant \& Equipment & $1,713.37$ & $1,528.53$ & $1,494.00$ \\
\hline Accumulated Depreciation & 410.19 & 371.22 & 315.31 \\
\hline Intangibles & 297.78 & 248.82 & 248.97 \\
\hline Deposits \& Other Assets & 221.34 & 312.33 & 172.04 \\
\hline Total Assets & $1,982.13$ & $1,922.07$ & $1,797.09$ \\
\hline Accounts Payable & 37.51 & 29.58 & 19.27 \\
\hline Current Portion of Long-Term Debt & 2.54 & 0.77 & 0.64 \\
\hline Income Taxes & 22.18 & 22.48 & 20.07 \\
\hline Other Current Liabilities & 150.08 & 143.48 & 142.52 \\
\hline Total Current Liabilities & 212.31 & 196.31 & 182.50 \\
\hline Deferred Revenues & 229.64 & 202.45 & 206.17 \\
\hline Long-Term Debt & 375.01 & 367.32 & 368.39 \\
\hline Other Long-Term Liabilities & 6.08 & 0.87 & 0.07 \\
\hline Total Liabilities & 823.04 & 766.95 & 757.13 \\
\hline Common Stock & 0.52 & 0.53 & 0.53 \\
\hline Capital Surplus & 621.53 & 698.40 & 699.88 \\
\hline Retained Earnings & 537.04 & 456.19 & 339.55 \\
\hline Total Shareholders' Equity & $1,159.09$ & $1,155.12$ & $1,039.96$ \\
\hline $\begin{array}{l}\text { Total Liabilities and } \\
\text { Shareholder's Equity }\end{array}$ & $1,982.13$ & $1,922.07$ & $1,797.09$ \\
\hline
\end{tabular}

Table C2: Income Statement

ABC Corporation

Income Statement

Years Ending

In millions of USD

\begin{tabular}{|c|c|c|c|}
\hline & $12 / 31 / 2008$ & 12/31/2007 & $12 / 31 / 2006$ \\
\hline Net Sales & 816.56 & 798.37 & 740.13 \\
\hline Cost of Goods Sold & 362.52 & 348.79 & 327.98 \\
\hline Gross Profit & 454.04 & 449.58 & 412.15 \\
\hline SG \& A Expense & 132.09 & 193.58 & 95.99 \\
\hline Depreciation \& Amortization & 80.21 & 56.83 & 50.89 \\
\hline Operating Income & 241.74 & 199.17 & 265.27 \\
\hline Non-Operating (Income) Loss & 53.25 & $(5.45)$ & $(8.67)$ \\
\hline Interest Expense & 15.63 & 12.35 & 12.69 \\
\hline Income Before Taxes & 172.86 & 192.27 & 261.25 \\
\hline Income Taxes & 86.67 & 75.47 & 101.88 \\
\hline Net Income & 86.19 & 116.80 & 159.37 \\
\hline
\end{tabular}


Table C3: Statement of Cash Flows

\begin{tabular}{|c|c|c|c|}
\hline \multicolumn{4}{|c|}{$\begin{array}{c}\text { ABC Corporation } \\
\text { Statement of Cash Flows } \\
\text { Years Ending }\end{array}$} \\
\hline \multicolumn{4}{|l|}{ In millions of USD } \\
\hline & $12 / 31 / 2008$ & $12 / 31 / 2007$ & $12 / 31 / 2006$ \\
\hline Net Income & $\$ \quad 86.19$ & $\$ \quad 116.80$ & $\$ \quad 159.37$ \\
\hline Depreciation/Amortization & 80.21 & 56.83 & 50.89 \\
\hline Net (Decrease) in Operating Assets/Liabilities & $(2.53)$ & $(17.90)$ & $(91.45)$ \\
\hline Other Adjustments-Net & 94.24 & 85.66 & 27.97 \\
\hline Net Cash Flow from Operating & 258.11 & 241.39 & 146.78 \\
\hline Net Purchase of Fixed Assets & (96.06) & $(110.19)$ & $(248.82)$ \\
\hline (Acquisition) Disposition of Businesses & $(87.04)$ & $(124.44)$ & $(23.82)$ \\
\hline (Increase) Decrease in Investments & 38.75 & $(69.80)$ & 106.80 \\
\hline Other Cash Flow from Investing & 0.06 & $(2.69)$ & $(0.38)$ \\
\hline Net Cash Flow from Investing & $(144.29)$ & $(307.12)$ & $(166.21)$ \\
\hline Issue (Repurchase) of Shares & $(81.16)$ & $(0.27)$ & $(0.07)$ \\
\hline (Net Repayment) of Debt & $(29.91)$ & $(0.64)$ & $(7.51)$ \\
\hline Dividends, Other Distribution & $(5.29)$ & $(4.27)$ & $(3.20)$ \\
\hline Other Cash Inflow (Outflow) & 0.17 & $(0.18)$ & $(0.01)$ \\
\hline Net Cash Flow from Financing & $(116.19)$ & $(5.36)$ & $(10.78)$ \\
\hline
\end{tabular}

Table C4: Financial information for individual investors 12/31/2008

\begin{tabular}{|c|c|c|c|}
\hline & John Burch & Joseph Cornwall & Charles Darwin \\
\hline Cash \& Equivalents & $\$ 750,000$ & $\$ 150,650$ & $\$ 1,450,000$ \\
\hline Investments: marketable securities & 720,000 & $80,750,000$ & $10,475,000$ \\
\hline Investments: non-marketable securities & $42,700,000$ & $45,850,000$ & $25,460,000$ \\
\hline Cash value of life insurance & & & 75,000 \\
\hline Total current assets & $\$ 44,170,000$ & $\$ 126,750,650$ & $\$ 37,460,000$ \\
\hline Retirement investment funds & $\$ 200,000$ & $\$ 214,295$ & $\$ 140,860$ \\
\hline Business investments & $30,500,000$ & & \\
\hline Personal real estate & 700,000 & $5,000,000$ & $4,000,000$ \\
\hline Personal assets - other & & & 800,000 \\
\hline Total assets & $\$ 75,570,000$ & $\$ 131,964,945$ & $\$ 42,400,860$ \\
\hline Total current liabilities & $\$ 100,500$ & & $\$ 29,500$ \\
\hline Mortgage payable & & 600,500 & 240,450 \\
\hline Net worth (equity) & $\$ 75,469,500$ & $\$ 131,364,445$ & $\$ 42,130,910$ \\
\hline Ownership in Silver Nugget LLC & $70.00 \%$ & $20.00 \%$ & $10.00 \%$ \\
\hline Required contribution to Silver Nugget LLC & $\$ 105,000,000$ & $\$ 30,000,000$ & $\$ 15,000,000$ \\
\hline
\end{tabular}


Table C5: Tax return information summarized for year ending 12/31/2008

Wages/Salaries

Taxable interest

Tax exempt interest

Dividends

Business income/loss

Capital gains/losses

Income from partnerships, S corporations \& trusts

Other income

Gross income

Personal and other deductions

Exemption

Taxable income

(gross income except tax-exempt income less deductions \& exemptions)

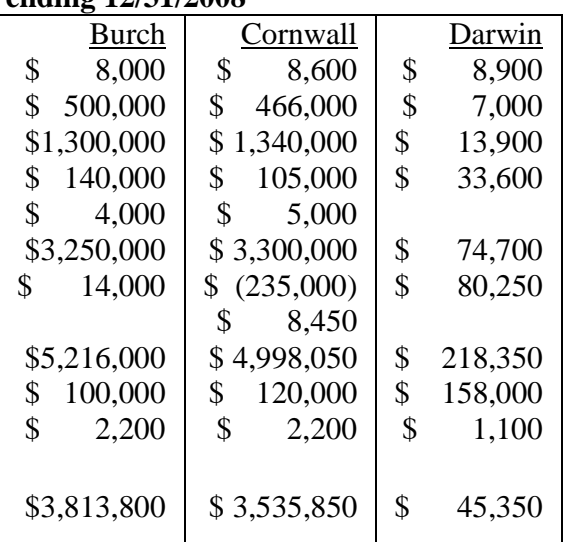

Table C6: Burch Family Trust: net worth and tax return information (12/31/2008)

\begin{tabular}{|l|r|}
\hline Net worth statement & \\
Cash \& Equivalents & $\$ 150,700,000$ \\
Investments: marketable securities & $120,500,000$ \\
Investments: non-marketable securities & $62,500,000$ \\
Loans to operating companies & $50,250,000$ \\
Business investments & $100,000,000$ \\
Total assets & $\$ 483,950,000$ \\
Total liabilities & $\$ 600,000$ \\
Net worth (equity) & $\$ 483,350,000$ \\
\hline Tax Return Information & $\$ 537,000$ \\
Dividends & 270,000 \\
Business income/loss & $(3,000)$ \\
Capital gains/losses & 48,000 \\
Rents, Royalties & 852,000 \\
Gross income & 86,000 \\
Investment interest expenses & 6,800 \\
Charitable contributions & 91,000 \\
Other deductions & \\
Taxable income & \\
(gross income except tax-exempt income less deductions \& exemptions) & $\$ 668,200$ \\
\hline
\end{tabular}

Table C7: Total project cost and Funding

\begin{tabular}{|l|r|}
\hline Pre-opening cost and payroll & $180,000,000$ \\
Mass transit improvement & $60,000,000$ \\
Contingencies and reserves & $2,500,000$ \\
Training & $50,000,000$ \\
Pre-opening cost & $7,500,000$ \\
Finance cost & $300,000,000$ \\
Total & $400,000,000$ \\
Property and equipment & $\$ 700,000,000$ \\
Total project cost & \\
Funding: & \\
Initial contribution - Silver Nugget LLC & $\$ 150,000,000$ \\
Initial contribution - ABC Corporation & $150,000,000$ \\
Total initial contributions & $300,000,000$ \\
Total asset backed loans & $400,000,000$ \\
Total funding & $\$ 700,000,000$ \\
\hline
\end{tabular}

